Collection: NFZ Summer School 2009 - Birmensdorf (Switzerland)

Long-term ecosystem research: understanding the present to shape the future

Guest Editor: Marcus Schaub (WSL, Switzerland)

\title{
Drought-induced mortality of Scots pines at the southern limits of its distribution in Europe: causes and consequences
}

\begin{abstract}
Giuggiola A ${ }^{(1)}$, Kuster TM ${ }^{(1)}$, Saha $\mathrm{S}^{(2)}$
Several severe drought events have been reported in southern Europe during recent decades. Drought has been found to increase the mortality of the southernmost populations of Scots pine forests in Mediterranean countries and in dry inner-alpine valleys. Therefore the ongoing global climate change is likely to endanger Scots pine in future decades. Carbon starvation might be the main cause of the increasing mortality rate due to less carbon uptake and consequently to high susceptibility to biotic attacks. Forest management, in particular, thinning and shrub removal could decrease the intensity of drought stress by decreasing competition for water resources and thus increasing carbon uptake. The ongoing climate change and adaptive forest management will both play an important role for the sustainability of this specie across southern regions of Europe.
\end{abstract}

Keywords: Scots pine, Drought, Tree mortality, Tree vitality, Europe, Thinning, Shrub removal

\section{Introduction}

Global climate change, in particular warming, has been observed in all parts of the world (IPCC 2001), including Europe, where several harmful drought periods have occurred during recent decades (Rebetez et al 2006). In future, the frequency of drough periods will probably increase as a consequence of global warming (IPCC 2007). Higher temperatures and heat waves wil lead to higher evapotranspiration (Schär et al. 2004, Beniston et al. 2007). Prolonged drought periods and concentrations of annual rainfall to heavy precipitations events are both predicted (Frei 2004, Frei et al. 2006,

(1) WSL Swiss Federal Institute for Forest Snow and Landscape, Zürcherstrasse 111, CH-8903 Birmensdorf (Switzerland); (2) Institute of Silviculture, University of

Freiburg, Tennenbacherstrasse 4, D-79085 Freiburg (Germany)

\section{@, Arnaud Giuggiola}

(arnaud.giuggiola@wsl.ch)

Received: May 25, 2010 - Accepted: May 31, 2010

Citation: Giuggiola A, Kuster TM, Saha S, 2010. Drought-induced mortality of Scots Pines at the southern limits of its distribution in Europe: causes and consequences. iForest 3: 95-97 [online: 2010-07-15] URL: http://www.sisef.it/iforest/show.php? id $=542$
Planton et al. 2008). A decrease in annual rainfall is also expected to take in the western Mediterranean basin (Rambal \& Hoff 1998)

Since water is an essential resource for most trees, and since it is also needed for transporting nutrients, drought periods can decrease trees' vigour (Martínez-Vilalta \& Piñol 2002), seriously reduce tree growth (Bigler et al. 2006) and ultimately lead to tree death (Rebetez \& Dobbertin 2004). Scots pine (Pinus sylvestris L.) is one of the most widespread conifer species on earth and is therefore a keystone species. Moreover, Scots pine is widely harvested for wood production in northern Europe and plays an important role in soil protection, recreation, and erosion prevention in mountain areas. Scots pine grows in very different climatic regions, from boreal regions in the north to dryer areas in the south of Europe (Martínez-Vilalta et al. 2009). Even though the mortality of Scots pine shows no clear trend in northern regions (Eid \& Tuhus 2001, Langstrom et al. 2001, Jutras et al. 2003, Ozolincius et al. 2005), recent studies indicate that the mortality rate of Scots pine growing at the southernmost limit of its distribution are increasing (Vertui \& Tagliaferro 1997, Martínez-Vilalta \& Piñol 2002, Rebetez \& Dobbertin 2004, Thabeet et al. 2009).

In this article, we will review: (1) the latest findings on the decline of Scots pine currently observed in the southern regions of Europe; (2) the physiological causes of Scots pine mortality during drought; and (3) possible implications for the future and for forest management.

\section{The decline of Scots pine in the southern regions of Europe}

In Mediterranean regions and in inner alpine valleys, the yearly precipitation is usually around $600 \mathrm{~mm}$ and summer temperatures are high. Scots pines growing in those regions experience water stress during the hottest and driest months. In the late 1980's, decline in Scots pine have been reported in Aosta Valley in Italy, where it was assumed that drought was the triggering factor or at least one of the main factors being involved (Vertui \& Tagliaferro 1997). In the north-east of Spain, Martínez-Vilalta \& Piñol (2002) report a high mortality rate up to $20 \%$ in during the dry years 1994 and 1998. Rebetez \& Dobbertin (2004) observed that $43 \%$ of Scots pine in the long-term observation plot in Valais, in Switzerland died between March 1996 and June 2002. The year 1998 was very dry and the plot received $397 \mathrm{~mm}$ of rainfall. Other studies have reported annual mortality rates higher than $5 \%$ in inner-alpine valleys and the Mediterranean basin (Rebetez \& Dobbertin 2004 Dieguez-Aranda et al. 2005, Dobbertin et al. 2005). However a steady decline has been recorded since the 1990s up to recent. Bigler et al. (2006) showed that single drought years during the last century considerably slowed down the growth of the Scots pine trees in the Swiss Rhône valley and increased the probability of mortality. A similar pattern was recorded in dry inner-alpine valleys in Austria, where extensive drought limited radial growth and influenced mortality of Scots pine (Oberhuber et al. 1998, Oberhuber 2001, Pichler \& Oberhuber 2007). More recently, Scots pine was affected by an extensive drought from 2003 to 2005 in the French Mediterranean region where growth, crown development and cone production decreased (Thabeet et al. 2009, Vennetier et al. 2009). An irrigation experiment in a dry region in Switzerland found that additional water increased growth rate, crown development and needle size (Dobbertin et al. 2010). Even though mortality was not explicitly mentioned, the results suggested that the observed decline in this area was caused by long-term drought.

In contrast, annual mortality in Scots pine forests in northern Europe is reported to be very low and typically stays below $1 \%$ (Eid \& Tuhus 2001, Langstrom et al. 2001, Jutras et al. 2003, Ozolincius et al. 2005). Those areas might also have low rainfall periods. 
However, because of the relative low temperatures, trees are less likely to experience severe droughts.

This feed suggests once more that in southern parts of Europe drought is the main factor or at least an important factor responsible for the decline of Scots pine.

\section{The physiological causes of Scots pine mortality during drought}

The water ascents under tension from the root to the leaf where loss of water occurs by transpiration. The water vapour deficit of the air is the driving force for water transport while the water in the soil is the source of water supply (Larcher 2003). When an appreciable period without precipitation occurs, water supply in the soil decreases and drought stress for trees increases and causes damage, resulting in either the dehydration of living cells (Larcher 2003) or in cavitation due to overly high tensions in the water columns of the xylem (Tyree \& Sperry 1989). Plants show different response strategies to drought. Scots pine has a xylem which is less resistant than some of the other pine species (Cochard 1992, MartínezVilalta \& Piñol 2002, Martínez-Vilalta et al. 2009). Therefore, trees need mechanisms to keep their water potential gradient within a non-damaging range (Buckley 2005) and to prevent hydraulic failure (McDowell et al. 2008). The most important mechanism is the regulation of the stomatal aperture. Scots pine reacts to drought stress with stomata closure (Martínez-Vilalta \& Piñol 2002), in order to reduce water loss and to prevent leaf wilting (Zweifel et al. 2007). During the extreme summer drought of 2003, Scots pine kept the stomata closed during the period June-August, while oaks have kept their stomata open (Zweifel et al. 2007). Tight control of the stomatal aperture is an adaptation to drought stress and helps keeping the trees' cells well watered, but closed stomata also reduce photosynthesis due to a lower carbon uptake (Körner 2003). This means, in periods of drought, Scots pine growth is reduced and can lead to tree death due to carbon starvation (McDowell et al. 2008). The carbon starvation theory claims that stomata closure helps to prevent water loss, but causes photosynthetic carbon to diminish and if the stomata remain closed for too long, the plant starves as a result of the continued metabolic demand for carbohydrates (McDowell et al. 2008). Moreover, Scots pine might have fewer defensive compounds against biotic agents, so that the drought effects could be amplified by pathogens or insect attacks, which could contribute to tree death (McDowell et al. 2008, Adams et al. 2009). In a warmer environment, where respiration rates increase with temperature, carbon starvation should be highly influenced by temperature, whereas hydraulic failure should not (Adams et al. 2009). However, extrapolating this study to future global warming and therefore concluding that carbon starvation is more likely to occur for tall trees than hydraulic failure is contradictory because enhanced leaf respiration is not an evidence of carbon reserve exhaustion at the tree level (Sala 2009, Leuzinger et al. 2009). Moreover, increased temperature may increase insect populations or infections of mistletoes may increase water stress due to high transpiration and thus both contribute to mortality (Dobbertin \& Rigling 2006).

\section{Implications for the future and the role of forest management}

Drought, pathogen attacks and the lack of appropriate silvicultural management in Scots pine forests in southern Europe could all contribute to the increased mortality of Scots pine in these areas. Reducing stand density increases water resources, nutrients and light for the remaining trees and therefore increase growth rate during the following years (Waring \& Schlesinger 1985). Thinning also reduces mortality by decreasing competition and removing suppressed tree, which do not benefit from sufficient light (Aussenac 2000). Related with drought, thinning decreases the interception of precipitation by the canopy (Aussenac 2000) and therefore increases the amount of water reaching the ground. However, microclimatic conditions may change and some reverse effects may appear: increasing light intensity the canopy and may lead to increased temperature at the ground level, which contributes to higher soil water evaporation and development of shrubs. Therefore, it is not clear yet if thinning practice could mitigate drought in those sensitive areas. The literature about the effect of understory vegetation on the water availability of overstory trees is sparse. One study has shown that dense understory vegetation can significantly decrease soil-water availability (Matsushima \& Chang 2007). An optimal stand density and removing of shrubs might improve water availability and reduce risks of cavitation for trees and thus have a positive effect on stomatal opening and consequently on carbon uptake. Improving carbon uptake should decrease mortality by allowing the tree to produce enough carbohydrates for the tree's metabolism and defenses against biotic attacks (Kolb et al. 2007)

\section{Conclusion}

Scots pine mortality is increasing dramatically at its southern distribution limits, showing that Scots pine grows at its physiological limits. In future decades, it is very likely that mortality rates will further increase as a consequence of global warming in these regions (IPCC 2007, Planton et al. 2008). Therefore, droughts during the up- coming decades might endanger the survival of Scots pine (Rebetez \& Dobbertin 2004) and possibly lead to replacement by other, more drought tolerant species.

The impact of the ongoing climate change and adapting forest management will both play an important role for the sustainability of Scots pine across southern regions of Europe. A better understanding of physiological causes of tree death, will also help to predict more precisely the possible shift of vegetation and help to adapt forest practices.

\section{Acknowledgements}

We would like to thank Marcus Schaub to provide us the opportunity to write this minireview paper in the framework of Summer School 2009. We are grateful to Dr. Matthias Dobbertin for his helpful comments and editorial work.

\section{References}

Adams HD, Guardiola-Claramonte M, Barron-Gafford GA, Villegas JC, Breshears D, Zou CB, Troch PA, Huxmann TE (2009). Temperature sensitivity of drought tree mortality portends increased regional die-off under global-changetype drought. Proceedings of the National Academy of Sciences 106: 7063-7066. - doi: 10.1073/pnas.0901438106

Aussenac G (2000). Interactions between forest stand and microclimate: Ecophysiological aspects and consequences for silviculture. Annals of Forest Science 57: 287-301. - doi: 10.1051/ forest:2000119

Beniston M, Stephenson DB, Christensen OB, Ferro CAT, Frei C, Goyette S, Halsnaes K, Holt T, Jylha K, Koffi B, Palutikof J, Scholl R, Semmler T, Woth K (2007). Future extreme events in European climate: an exploration of regional climate model projections. Climatic Change 81: 71-95. - doi: 10.1007/s10584-0069226-z

Bigler C, Bräker OU, Bugmann H, Dobbertin M, Rigling A (2006). Drought as an Inciting Mortality Factor in Scots Pine Stands of the Valais, Switzerland. Ecosystems 9: 330-343. - doi: 10.1007/s10021-005-0126-2

Buckley TN (2005). The control of stomata by water balance. New Phytologist 168: 275-292. doi: 10.1111/j.1469-8137.2005.01543.x

Cochard H (1992). Vulnerability of several conifers to air embolism. Tree Physiology 11: $73-$ 83. - doi: 10.1093/treephys/11.1.73

Dieguez-Aranda U, Castedo-Dorado F, AlvarezGonzalez JG, Rodriguez-Soalleiro R (2005). Modelling mortality of Scots pine (Pinus sylvestris L.) plantations in the northwest of Spain. European Journal of Forest Research 124: 143-153. - doi: 10.1007/s10342-004-0043-5

Dobbertin M, Mayer P, Wohlgemuth T, Feldmeyer-Christe E, Graf U, Zimmermann NE, Rigling A (2005). The decline of Pinus sylvestris L. forests in the swiss Rhone Valley - a result of drought stress? Phyton - Annales Rei Botanicae 45: 153-156. [online] URL: http://cat.inist.fr/? 
aModele $=$ afficheN\&cpsidt $=18366510$

Dobbertin M, Rigling A (2006). Pine mistletoe (Viscum album ssp. austriacum) contributes to Scots pine (Pinus sylvestris) mortality in the Rhône valley of Switzerland. Forest Pathology 36: 309-322. - doi: 10.1111/j.1439-0329.2006 00457.x

Dobbertin M, Eilmann B, Bleuler P, Giuggiola A, Graf Pannatier E, Landolt W, Schleppi P, Rigling A (2010). Effect of irrigation on needle morphology, shoot and stem growth in a drought-exposed Pinus sylvestris forest. Tree physiology (in the press).

Eid T, Tuhus E (2001). Models for individual tree mortality in Norway. Forest Ecology and Management 154: 69-84. - doi: 10.1016/S03781127(00)00634-4

Frei C (2004). Eidgenössische Technische Hochschule (Zürich) Institut für Atmosphäre und Klima, and MeteoSchweiz, 2004. Klimazukunft der Schweiz - Eine probabilistische Projektion. MeteoSchweiz, Zürich, pp. 8.

Frei C, Scholl R, Fukutome S, Schmidli J, Vidale PL (2006). Future change of precipitation extremes in Europe: intercomparison of scenarios from regional climate models. Journal of Geophysical Research 111: D06105. - doi: 10.1029/ 2005JD005965

IPCC (2001). Climatic change 2001: The Scientific Basis. In: "Contribution of Working Group I to the Third Assessment Report of the IPCC" (Houghton JT, Ding Y, Griggs DJ, Noguer M, van der Linden PJ, Dai X, Manskell K, Johnson CA eds). University Press, Cambridge, UK, pp 881 .

IPCC (2007). Climate Change 2007 - Impacts, adaptation and vulnerability. In: "Contribution of Working Group II to the Fourth Assessment Report of the IPCC" (Parry M, Canziani O, Palutikof J, van der Linden P, Hanson C eds), University Press, Cambridge, UK.

Jutras S, Hokka H, Alenius V, Salminen H (2003). Modeling mortality of individual trees in drained peatland sites in Finland. Silva Fennica 37: 235 251. [online] URL: http://www.metla.fi/silvafennica/full/sf37/sf372235.pdf

Körner C (2003). Alpine plant life: functional plant ecology of high mountain ecosystems. Springer, Berlin, Heidelberg, Germany.

Langstrom B, Annila E, Hellqvist C, Varama M, Niemela P (2001). Tree mortality, needle biomass recovery and growth losses in Scots pine following defoliation by Diprion pini (L.) and subsequent attack by Tomicus piniperda (L.) Scandinavian Journal of Forest Research 16 342-353. - doi: 10.1080/02827580152496731

Larcher W (2003). Physiological plant ecology ecophysiology and stress physiology of functio- nal groups. Springer, Berlin, Germany, pp. 513. Leuzinger S, Bigler C, Wolf A, Körner C (2009). Poor methodology for predicting large-scale tree die-off. Proceedings of the National Academy of Sciences 106 (38): E106. - doi: 10.1073/ pnas.0908053106

Kolb TE, Agee JK, Fulé PZ, McDowell NG, Pearson K, Sala A, Waring RH (2007). Perpetuating old ponderosa pine. Forest Ecology and Management 249: 141-157. - doi: 10.1016/j.foreco.2007. 06.002

Martínez-Vilalta J, Piñol J (2002). Drought-induced mortality and hydraulic architecture in pine populations of the NE Iberian Peninsula. Forest Ecology and Management 161: 247-256. doi: 10.1016/S0378-1127(01)00495-9

Martínez-Vilalta J, Cochard H, Mencuccini M, Sterck F, Herrero A, Korhonen JFJ, Llorens P, Nikinmaa E, Nolè A, Poyatos R, Ripullone F, Sass-Klaassen U, Zweifel R (2009). Hydraulic adjustement of Scots pine across Europe. New Phytologist 194: 353-364. - doi: 10.1111/j.14698137.2009.02954.x

Matsushima M, Chang SX (2007). Effects of understory removal, $\mathrm{N}$ fertilization, and litter layer removal on soil $\mathrm{N}$ cycling in a 13 -year-old white spruce plantation infested with Canada bluejoint grass. Plant and Soil 292: 243-258. - doi: 10.1007/s11104-007-9220-x

McDowell N, Pockman WT, Allen CD, Breshears DD, Cobb N, Kolb T, Plaut J, Sperry J, West A, Williams DG, Yepez EA (2008). Mechanisms of plant survival and mortality during drought: why do some plants survive while others succumb to drought? New Phytologist 178: 719-739. - doi: 10.1111/j.1469-8137.2008.02436.x

Oberhuber W, Stumböck M, Kofler W (1998). Climate-tree-growth relationships of Scots pine stands (Pinus sylvestris L.) exposed to soil dryness. Trees 13: 19-27. - doi: 10.1007/ PL00009734

Oberhuber W (2001). The role of climate in the mortality of Scots pine (Pinus sylvestris L.) exposed to soil dryness. Dendrochronologia 19: 4555

Ozolincius R, Miksys V, Stakenas V (2005). Growth-independent mortality of Lithuanian forest tree species. Scandinavian Journal of Forest Research 20: 153-160. - doi: 10.1080/ 14004080510042164

Pichler P, Oberhuber W (2007). Radial growth response of coniferous forest trees in an inner Alpine environment to heat-wave in 2003. Forest Ecology and Management 242: 688-699. - doi: 10.1016/j.foreco.2007.02.007

Planton S, Deque M, Chauvin F, Terray L (2008). Expected impacts of climate change on extreme climate events. Comptes Rendus Geoscience
340: 564-574. - doi: 10.1016/j.crte.2008.07.009 Rambal S, Hoff C (1998). Mediterranean ecosystems and fire: the treats of global change. In: "Large Forest Fires" (Moreno JM ed). Backhuys, Leiden, The Netherlands.

Rebetez M, Dobbertin M (2004). Climate change may already threaten Scots pine stands in the Swiss Alps. Theoretical and Applied Climatology 79: 1-9. - doi: 10.1007/s00704-004-0058-3

Rebetez M, Mayer H, Dupont O, Schindler D, Gartner K, Kropp JP, Menzel A (2006). Heat and drought 2003 in Europe: a climate synthesis. Annals of Forest Science 63: 569-577. - doi: 10.1051/forest:2006043

Sala A (2009). Lack of direct evidence for the carbon-starvation hypothesis to explain drought-induced mortality in trees. Proceedings of the National Academy of Sciences 106 (26): E68. - doi: 10.1073/pnas.0904580106

Schär C, Vidale PL, Luthi D, Frei C, Haberli C, Liniger MA, Appenzeller C (2004). The role of increasing temperature variability in European summer heatwaves. Nature 427: 332-336. - doi: 10.1038 /nature 02300

Thabeet A, Vennetier M, Gadbin-Henry C, Denelle N, Roux M, Caraglio Y, Vila B (2009). Response of Pinus sylvestris L. to recent climatic events in the French Mediterranean region. Trees 23: 843-853. - doi: 10.1007/s00468-009-0326-Z

Tyree MT, Sperry JS (1989). Vulnerability of xylem cavitation and embolism. Annual Review of Plant Physiology and Plant Molecular Biology 40: 19-38. - doi: 10.1146/annurev.pp.40.060189. 000315

Vennetier M, Thabeet A, Gadbin-Henry C, Ripert C, Prevosto B, Borgniet L, Vila B, Guibal F, Ray R, Buron, Zanetti C (2009). Conséquences de la canicule et de la sécheresse 2003 sur les pins méditerranéens. In: "Sécheresse et canicule 2003. Contribution des dispositifs de suivi et d'observation des forêts à la quantification des effets immédiats et à court terme" (Landman G Landeau $\mathrm{S}$ eds). QUAE, Paris, France (in the press).

Vertui F, Tagliaferro F (1997). Scots pine (Pinus sylvestris L.) die-back by unknow causes in the Aosta valley, Italy. Chemosphere 36: 1061-1065. - doi: 10.1016/S0045-6535(97)10172-2

Waring RH, Schlesinger WH (1985). Forest Ecosystems: Concepts and Management. Academic Press Inc., Orlando, FL, USA, pp. 340.

Zweifel R, Steppe K, Sterck FJ (2007). Stomatal regulation by microclimate and tree water relations: interpreting ecophysiological field data with a hydraulic plant model. Journal of Experimental Botany 58: 2113-2131. - doi: 10.1093/ jxb/erm050 